\title{
Natural Regeneration of Pinus canariensis Chr. Sm. Ex DC in Buch in Forest Plantations After Thinning
}

\author{
José Ramón Arévalo* and José María Fernández-Palacios
}

\author{
Departamento de Ecología, Universidad de La Laguna. La Laguna, Tenerife, 38206, Spain
}

\begin{abstract}
Thinning is indispensable for the sustainable development and naturalization of forest plantations. In order to reveal the effect of different thinning intensities on the natural regeneration of a plantation of Pinus canariensis, we followed for two years the density of seedlings, saplings of 1 year, saplings of 1-2 years and saplings of $>2$ years in plots at different thinning intensities (control, 20 and 50\%). Our analysis revealed that seedling density and density of saplings $>2$ years were higher in plots thinned by $50 \%$ of their total basal area, whereas the other categories were significantly more abundant in control plots. These results suggest an important impact of light in the germination of seedlings, while a more covered canopy will increase the probability of establishment of saplings 1 and 1-2 years old. However, for saplings $>2$ years, the lack of space found in control plots largely determined their low abundance.

We suggest that canopy openness should be much larger than is provided by the currently applied treatments, offering at least a $40-50 \%$ open canopy for a few years (it should ensure that trees around the gap are unable to close the canopy with their branches). As our results show, germination in 50\% thinned plots is high, but high mortality is also expected, with probably no more than $5 \%$ of the individuals remaining after 3 years.
\end{abstract}

Keywords: Canary islands, regeneration dynamics, sampling, seedling, thinning.

\section{INTRODUCTION}

Thinning is indispensable for the sustainable development and naturalization of forest plantations $[1,2]$. In order to naturalize pine plantations, it is required to enhance natural regeneration by appropriately selecting and cutting with the appropriate intensity [3]. Patch dynamics should be favored in plantations to restore natural processes such as interactions between differently developed patches and thus recreating the ecological processes for self-maintenance [4]. These patch dynamics should be diverse enough to allow germination and emergence of conifer seedlings [5].

The main objective of the plantations analyzed in this study was to restore the Canarian pine (Pinus canariensis Chr. Sm. Ex DC in Buch) forest that was heavily disturbed and logged during the last 5 centuries after the European colonization of the Canary Islands [6]. In the last 60 years large areas of Tenerife Island have been reforested, but with a lack of subsequent management or monitoring. In recent years, however, authorities have re-considered the usefulness of the plantations, moving away from the idea of using them solely as exploitable natural resources and toward a management practice that will restore the pine forest ecosystem. Unfortunately, little information is available on the pine forests' dynamics, and the few quantitative studies that exist deal specifically with fire effects $[7,8]$.

Although plantations have been very common in the islands of the Canarian archipelago, management activities in

*Address correspondence to this author at the Departamento de Ecología, Universidad de La Laguna. La Laguna, Tenerife, 38206, Spain;

Tel: +34 922318 628; Fax: +34922318 411; E-mail: jarevalo@ull.es these plantations such as thinning started 30 years ago. It was not until 20 years ago that the first plots to monitor the effects of management procedures were established. We investigated the effect of thinning intensity and climate parameters (temperature and precipitation) on temporal dynamics of regeneration and establishment of seedlings and saplings. We started this study ten years after the treatments to reveal later effects on regeneration instead of early effects. The hypotheses we tested were: Thinning increases germination and survivorship of the seedlings over a long-term period ( $>10$ years); the $50 \%$ thinning intensity applied is allowing the establishment of new individuals of Pinus canariensis.

\section{MATERIAL AND METHODS}

\section{Study Site}

The study was conducted in the northeast slope of the Corona Forestal Natural Park in Tenerife $\left(28^{\circ} 19^{\prime} \mathrm{N}, 16^{\circ} 34^{\prime}\right.$ W), Canary Islands (Fig. 1). The park is $\sim 46,336$ ha, and about $25 \%$ of the park has been reforested with Pinus canariensis (except $2 \%$ in which Pinus radiata was used). These reforestations were made between 1930-40 [9]. The sites selected for this study were planted between 19481952.

The dominant shrub species on the windward site are Erica arborea and Adenocarpus viscosus, while A. viscosus and Chamaecytisus proliferus dominate on the leeward site. A high number of annual and ruderal species are present at both sites, especially in the plots close to trails or those affected by other disturbances [10].

The annual precipitation of the park reaches $900 \mathrm{~mm}$, but it can be twice this amount if fog drip is considered [11]. The 


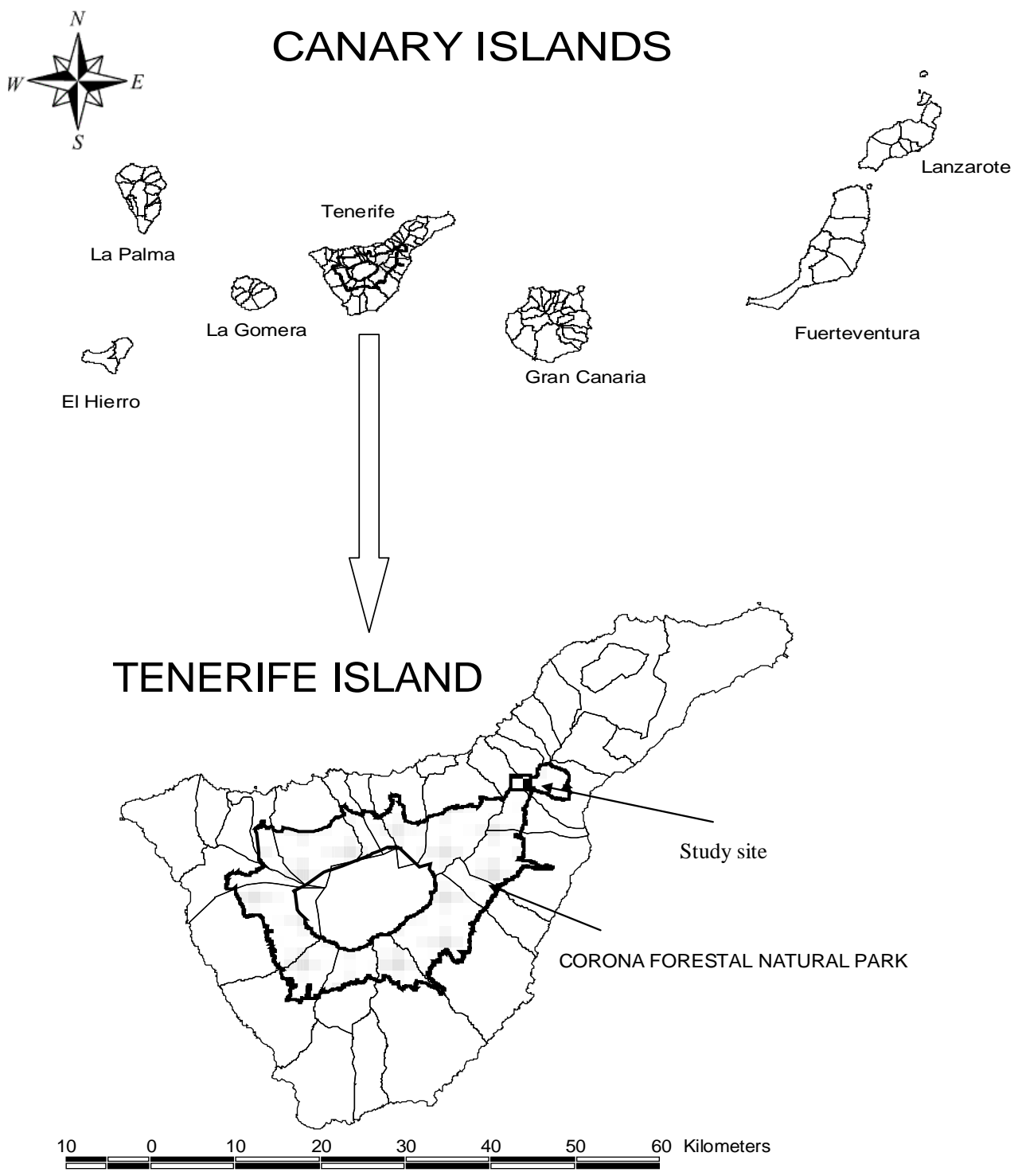

Fig. (1). Map of the Canary Islands. The map of Tenerife Island indicates the study area in a dark square. The last figure indicates the location of the plots.

mean annual temperature is close to $15^{\circ} \mathrm{C}$ with minimal annual and daily fluctuations. Frost events may occur a few days a year. Soils at the study site have been classified in the order Entisol, suborder Orthens [12]. Additional information on the sites can be found in Blanco et al. [13]. Nomenclature follows the check-list of Izquierdo et al. [14].

\section{The Species}

Pinus canariensis is a large evergreen tree, growing to $30-45 \mathrm{~m}$ tall and $1.5 \mathrm{~m}$ trunk diameter, and exceptionally up to $60 \mathrm{~m}$ tall and $2.5 \mathrm{~m}$ diameter. The species has a great resistance to fire [7], producing glaucous (bluish-green) epicormic shoots from the lower trunk (after fire), basal sprouts and serotinuous cones. It also has high resistance to cold temperatures [15]. Fire rate in this study is lower than expected for a natural rate due to the prevention activities of the managers of the Park [8].
The dispersion of seeds is favoured by wind because the cones are opened in the tree and the seeds have a long wing (larger than the size of the seed) that allows dispersion further from the father trees. Due to the dispersal characteristics of the species is highly competitive with other introduced species of pines [16].

Natural populations of Pinus canariensis have lower regeneration density and lower density and basal area of trees [17] than reforested stands (Table 1). Remnants of natural $P$. canariensis stands are poorly represented in Tenerife.

\section{Sampling Design}

During the summer of 1988, the study site (a Pinus canariensis plantation) was selected for the Consejería de Política Territorial [18]. Three blocks comprising three plots were established in the site. Each of the three plots was 625 $\mathrm{m}^{2}$ (see Table 2 for abiotic parameters). Thinning started in all these blocks in 1988. A previous treatment for all the 
plots was elimination of dead trees in 1975 and moderate thinning (around 5-10\% of dominant trees in the plots) in 1982. In each plot we noted orientation, altitude, slope and measured canopy closure using a convex spherical densiometer [19].

Table 1. Biotic Characteristics of Several Plots in Natural Stands of Tenerife. Density of Trees $>5 \mathrm{~cm}$ Diameter. Regeneration Mainly Includes Seedlings and Saplings Up to 2 Years (Blanco et al. 1989)

\begin{tabular}{|c|c|c|c|c|}
\hline Stand & $\begin{array}{c}\text { Plot Size } \\
\left(\mathbf{m}^{\mathbf{2}}\right)\end{array}$ & $\begin{array}{c}\text { Density } \\
\text { (ind./ha) }\end{array}$ & $\begin{array}{c}\text { Regeneration } \\
\text { (ind/ha) }\end{array}$ & Comments \\
\hline \hline Vilaflor & 225 & 180 & $<10$ & Natural stand \\
\hline Pinar & 225 & 490 & $<10$ & Natural stand \\
\hline Chio & 225 & 220 & $<10$ & Natural stand \\
\hline Chafa & 225 & 130 & $<10$ & Natural stand \\
\hline
\end{tabular}

Trees in each plot were classified by relative height as dominant, codominant, intermediate and overtopped. We measured diameter at breast height $(\mathrm{DBH})$ and height of 30 randomly chosen trees (except in some plots with less than 30 trees, where all trees where measured; treatment $C$, see below). We randomly assigned one of three treatments to each plot, having each block all three treatments: Control plots (elimination of dead trees only, regular treatment in all plantations to remove fuel for possible wild fires); $20 \%$ thinning, meaning a reduction of $20 \%$ of basal area (hereafter thin $20 \%$ ); $50 \%$ thinning (hereafter thin50\%). Only intermediate and overtopped trees were removed. During the summer of 1999, both sites were resampled (first sampling in 1988) and we measured DBH, tree height, canopy height (height of the canopy of each tree, measuring from the first live branch to the ground) and the number of dead trees since 1988. Pine cones were counted during a single period in the plots (March-May 2001). Before the counting, we removed all pine cones from the plots and counted new ones found in the ground during the indicated period.

Table 2. General Characteristics of the Plots

\begin{tabular}{|c|c|c|c|c|c|c|c|}
\hline \multirow{2}{*}{$\underset{(* *)}{\text { Plot No. }}$} & \multirow{2}{*}{ Aspect } & \multirow{2}{*}{$\begin{array}{c}\text { Slope } \\
\left({ }^{\circ}\right)\end{array}$} & \multirow{2}{*}{$\begin{array}{c}\text { Height } \\
\text { (m) }\end{array}$} & \multicolumn{3}{|c|}{ Cover" } & \multirow{2}{*}{$\begin{array}{c}\text { Canopy } \\
\text { Closure } \\
(\%)\end{array}$} \\
\hline & & & & Rock & Soil & Litter & \\
\hline 1 & $\mathrm{~S}$ & 12 & 1600 & 4 & 2 & 9 & 90 \\
\hline 2 & $\mathrm{~S}$ & 4 & 1600 & 5 & 2 & 9 & 88 \\
\hline 3 & $\mathrm{~S}$ & 4 & 1590 & 5 & 1 & 9 & 85 \\
\hline 4 & $\mathrm{~S}$ & 15 & 1580 & 2 & 3 & 9 & 95 \\
\hline 5 & $\mathrm{~S}$ & 25 & 1610 & 1 & 3 & 9 & 85 \\
\hline 6 & S & 31 & 1600 & 2 & 4 & 9 & 75 \\
\hline 7 & S & 17 & 1600 & 4 & 2 & 9 & 85 \\
\hline 8 & $\mathrm{~S}$ & 8 & 1620 & 5 & 1 & 9 & 90 \\
\hline 9 & $\mathrm{~S}$ & 4 & 1620 & 5 & 1 & 9 & 95 \\
\hline
\end{tabular}

(*).- Cover classes: 1: traces, 2: 0-1\%, 3: 1-2\%, 4: 2-5\%, 5: 5-10\%, 6: 10-25\%, 7: 25$50 \%, 8: 50-75 \%, 9:>75 \%$.

$(* *)$.- The numbers of the plots have no ordinal meaning.
We monitored the regeneration of Pinus canariensis in all the plots $\left(625 \mathrm{~m}^{2}\right)$ every $15-20$ days indicating the number of seedlings (hereafter se, if they still have cotyledons), sapling category 1 (hereafter sa_1, without cotyledons but the whole plant photosynthetic), sapling category 2 (hereafter sa_2, greater than one and less than two years old, and some part of the main stem producing bark) and sapling category 3 (herafter sa_3, more than two years old, with two differential growth parts in the main stem). We started in March 2000 and finished the monitoring in April 2002.

\section{Statistical Analysis}

We used non parametric Friedman tests (with $\alpha=0.05$ ) to compare densities of the different categories of regeneration (se, sa_1, sa_2 and sa_3) with treatment group as the factor and the data grouped by the date of the sampling. Differences in pine cone production in April-March (once pine cones reach maturity) were analysed using the KruskalWallis test. We used non parametric tests because the lack of normality and homocedasticity of the data. Normality of the data was tested with the Shapiro-Wilk test, and homoscedasticity of the data was tested with a multiple $F$ test (using $\alpha=0.05$ in both cases). We correlated, using the bivariate Pearson correlation coefficient, seedling and sapling densities at different categories of the treatments at each date with temperature and humidity values of the same date (mean, maximum and minimum) obtained from meteorological stations near the plots. For these analysis we also used the Bonferroni multiple test correction [20]. Basic statistical methods followed Zar [21] and were applied with the SPSS statistical package [22].

Climate data from meteorological stations located near the plots revealed some differences among years (El Gaitero Meterological Station, unpublished data), but similar patterns as expected. Monthly precipitation values were larger during winter months, especially February and March. Temperature and humidity showed an opposite pattern and the values where similar among years. Temperatures were higher in July and lower in February-March (Fig. 2).

\section{Mean production of cone pines}

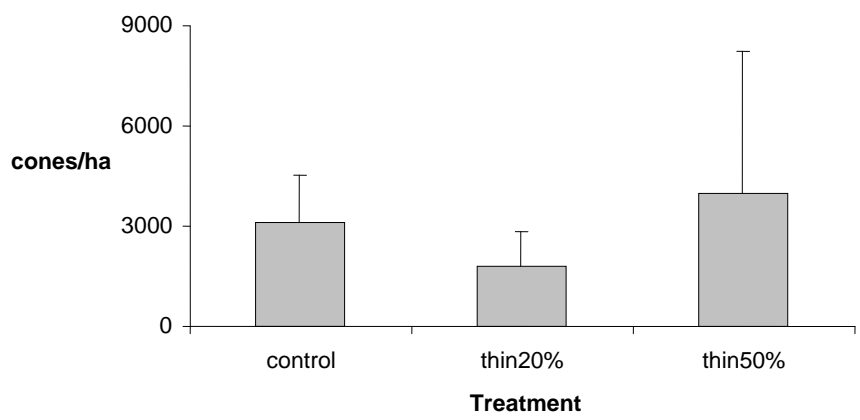

Fig. (2). (a) Monthly precipitation values in the Gaitero station (a meteorological station located less than 100 meters from the plots), (b) temperature values and (c) humidity values.

\section{RESULTS}

Although the study was developed in a plantation with relative homogenous environmental conditions, some minor heterogeneity was present among the plots. Altitude ranged 
Table 3. Biotic Characteristics of the Canopy in Each Plot. Mean Height is Calculated from the Random Selection of 30 Trees in the Plot. Tree Canopy is the Mean High of the First Branch in the Trunk. Sprouts are Considered Basal Sprouts Produce form the Coppice of the Logged Tree

\begin{tabular}{|c|c|c|c|c|c|c|c|c|c|c|c|c|c|}
\hline \multirow{3}{*}{ Treatments } & \multirow{3}{*}{ Codes } & \multicolumn{2}{|c|}{ Density (Ind/ha) } & \multicolumn{2}{|c|}{ Basal Area $\left(\mathrm{m}^{2} / \mathrm{ha}\right)$} & \multirow{3}{*}{1999} & \multirow{2}{*}{\multicolumn{2}{|c|}{$\begin{array}{c}\text { Mean Height (m) } \\
1988\end{array}$}} & \multirow{2}{*}{\multicolumn{2}{|c|}{1999}} & \multirow{3}{*}{$\begin{array}{c}\text { Sprouts (ha) } \\
1999\end{array}$} & \multirow{2}{*}{\multicolumn{2}{|c|}{$\begin{array}{c}\begin{array}{c}\text { Tree Canopy } \\
\text { Height (m) }\end{array} \\
1999\end{array}$}} \\
\hline & & 1988 & 1999 & 1988 & 1988 & & & & & & & & \\
\hline & & $\mathrm{Bt}^{*}$ & & $\mathbf{B t}^{*}$ & $\mathbf{A t}^{* * *}$ & & Mean & Std. ${ }^{* * * *}$ & Mean & Std. & & Mean & Std \\
\hline control & $\mathrm{a}$ & 1,456 & 1,424 & 59.76 & 59.26 & 75.24 & 15.49 & 6.15 & 18.06 & 2.08 & 0 & 10.48 & 2.64 \\
\hline control & $\mathrm{a}$ & 1,664 & 1,520 & 65.65 & 62.50 & 73.76 & 15.52 & 2.07 & 19.43 & 2.25 & 0 & 11.89 & 2.37 \\
\hline control & $\mathrm{a}$ & 2,448 & 1,920 & 73.24 & 66.98 & 81.88 & 15.95 & 5.20 & 18.76 & 2.07 & 0 & 12.65 & 1.76 \\
\hline thin $20 \%$ & $\mathrm{~b}$ & 1,504 & 1,216 & 58.15 & 50.23 & 63.87 & 15.88 & 4.29 & 18.71 & 2.00 & 224 & 11.11 & 2.07 \\
\hline thin $20 \%$ & $\mathrm{~b}$ & 1,600 & 1,264 & 52.62 & 44.97 & 51.97 & 14.25 & 1.70 & 16.47 & 2.59 & 624 & 10.35 & 1.95 \\
\hline thin $20 \%$ & $\mathrm{~b}$ & 2,000 & 1,360 & 68.32 & 55.89 & 64.59 & 15.99 & 3.51 & 20.16 & 3.12 & 0 & 14.12 & 2.91 \\
\hline thin $50 \%$ & $\mathrm{c}$ & 1,312 & 528 & 54.93 & 29.89 & 41.15 & 17.39 & 5.92 & 19.59 & 1.42 & 1792 & 9.63 & 1.74 \\
\hline thin $50 \%$ & $\mathrm{c}$ & 1,600 & 800 & 43.81 & 27.09 & 34.90 & 16.18 & 1.58 & 20.16 & 2.22 & 256 & 10.47 & 2.38 \\
\hline thin $50 \%$ & $\mathrm{c}$ & 1,488 & 544 & 60.76 & 29.81 & 40.32 & 17.27 & 5.39 & 20.58 & 2.34 & 992 & 10.97 & 1.99 \\
\hline
\end{tabular}

(*) Bt: Before thinning.

$(* *)$ At: After thinning.

$(* * *)$ Std.: Standard deviation.

between 1580 and $1620 \mathrm{~m}$ and slope from 4 to 31 sexageximal degrees. Canopy closure should be directly affected by the treatments, but the difference was only $10 \%$ between treatments (Table 2).

Changes in basal area immediately after thinning and ten years later are shown in Table $\mathbf{3}$. There was a high variability in basal area before treatments. Pine height did not change significantly among treatments. Sprouts were present only in thin $50 \%$ plots (Table 3). The mean number of cones produced did not differ significantly among treatments (g.l. $=2$, $\chi^{2}=0.800$, non significant; Fig. 3).

The correlations between seedling and sapling density with climatic parameters revealed that only sa_1 was significantly correlated $(\mathrm{P}<0.05)$ with temperature independently of the treatment, while the rest of the correlations did not reveal significant relationships (Table 4).

The comparisons of regeneration among the different treatments offered different results depending on the regeneration category (seedlings, sa_1, sa_2 or sa_3). In the case of seedlings the analysis revealed significant differences $\left(\mathrm{n}=43, \mathrm{~g} .1 .=2 ; \chi^{2}=32.87, \mathrm{P}<0.01\right)$, with higher values of regeneration for thin $50 \%$ plots. However, for sa_1 and sa_2 higher values were found in control plots $(n=43$, g.1 $=2$; $\chi^{2}=20.18$ and $\chi^{2}=13.41$ respectively, $\mathrm{P}<0.01$ ). Finally, for sa 3 , higher values of densities were found again in thin $50 \%$ plots $\left(\mathrm{n}=43, \mathrm{~g} .1 .=2 ; \chi^{2}=18.58, \mathrm{P}<0.01\right)$.

We did not monitor the fate of individual seedlings and saplings, although some estimation can be made about survivorship of the individuals' based in the accounts. For the three treatments, the approximate survival rate from seedling to sa_3 was around $5 \%$ (if we compared the maximum values along two years in each category). With respect to the temporal dynamics of regeneration, fluctuations were marked for seedlings and sa_1, having a maximum in density during the winter period through spring and mortality close to $90 \%$ during the summer season. This temporal pattern was consistent across the three treatments. In the case of sa 1 , as expected, there was a delay of one-two months in seedlings reaching maximum regeneration density for the year. Also, during the year 2001 the regeneration density presented higher values for sa_1. However, in the case of sa_2 and sa_3, temporal dynamics were less marked, especially in treatments thin $20 \%$ and thin $50 \%$ (Fig. 4).

Table 4. Pearson Correlation Coefficients Between Sapling (sa_1) Density in the Control Plots, in the $20 \%$ Thinned Plots (Thin20\%), the 50\% Thinned Plots (Thin50\%) and Three Temperature Measures in Each Sampling Period ( $n=42$, All are Significant for a p $<0.05$ After Applying Bonferroni Multiple Tests Correction)

\begin{tabular}{|c|c|c|c|}
\hline \multirow{2}{*}{} & \multicolumn{3}{|c|}{ Temperatures } \\
\cline { 2 - 4 } & Maximum & Minimum & Mean \\
\hline \hline sa_1 control & 0.490 & 0.527 & 0.502 \\
\hline sa_1 thin20\% & 0.543 & 0.540 & 0.550 \\
\hline sa_1 thin50\% & 0.571 & 0.552 & 0.574 \\
\hline
\end{tabular}

\section{DISCUSSION}

Large gaps have been demonstrated to affect germination and establishment of Pinus species [2, 23, 24]. Canary Islands have subtropical climate where seasons are less marked, so factors affecting germination and establishment at different periods will be mainly related with precipitation and temperature.

After ten years of thinning we can see how canopy closure is very similar among treatments (only a $10 \%$ difference). So, the main effect of thinning, canopy openness, will be completely minimized after a few years. On the other 
a)

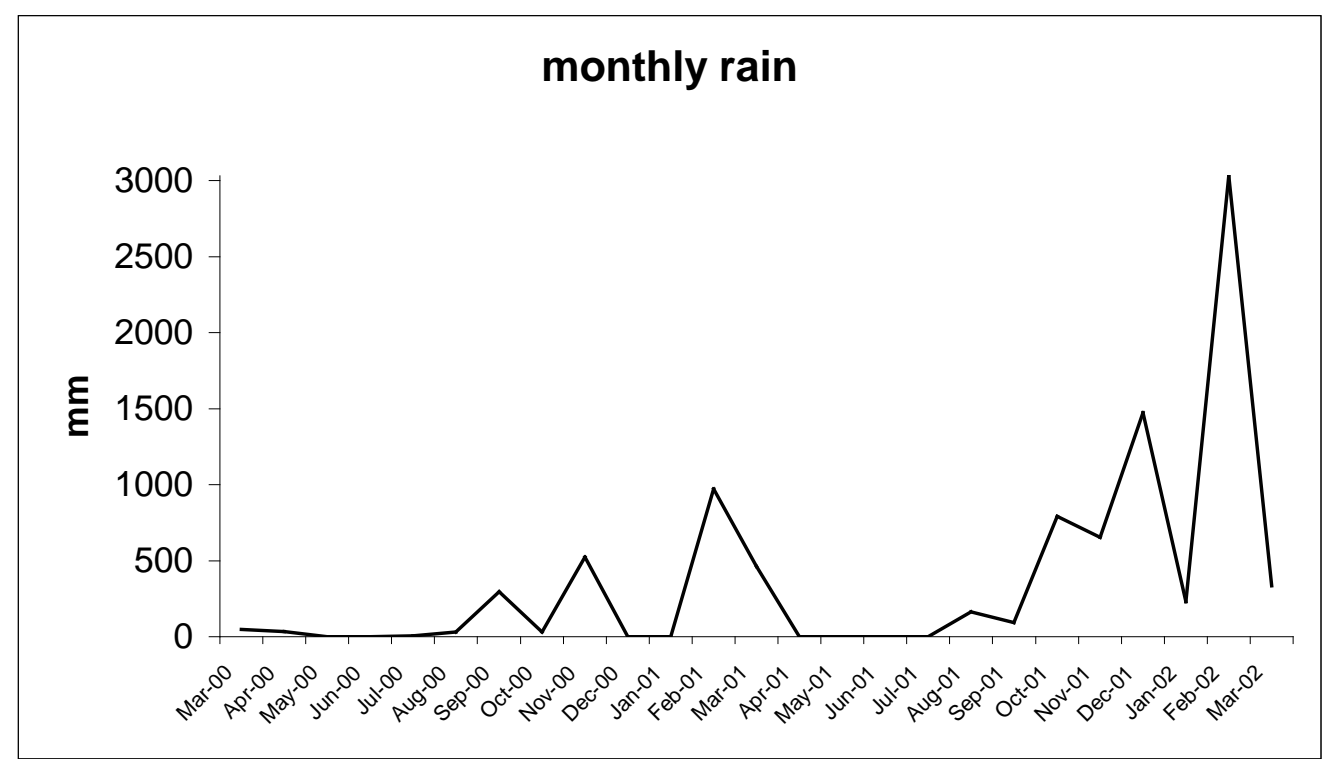

b)

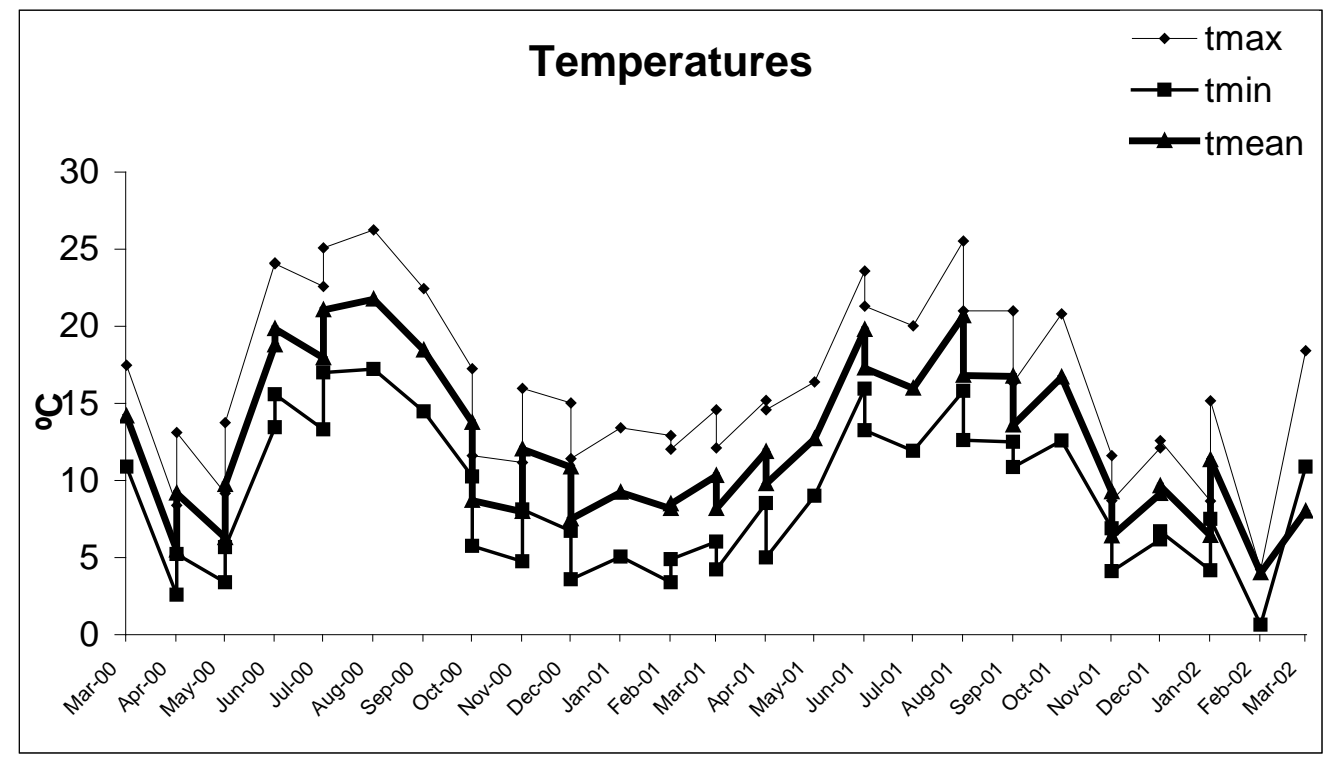

c)

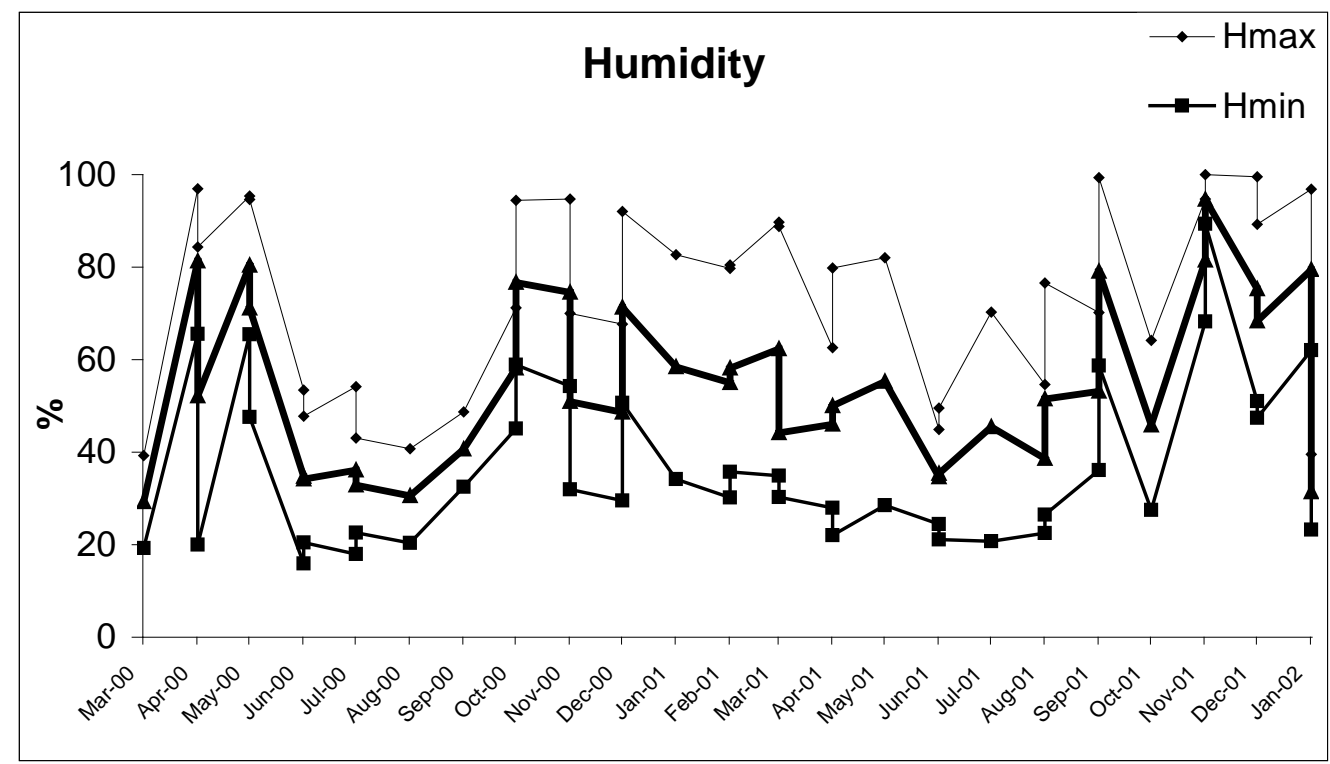

Fig. (3). Mean values and standard deviations for pine cone production during March-May 2001. No significant differences were found among treatments. 

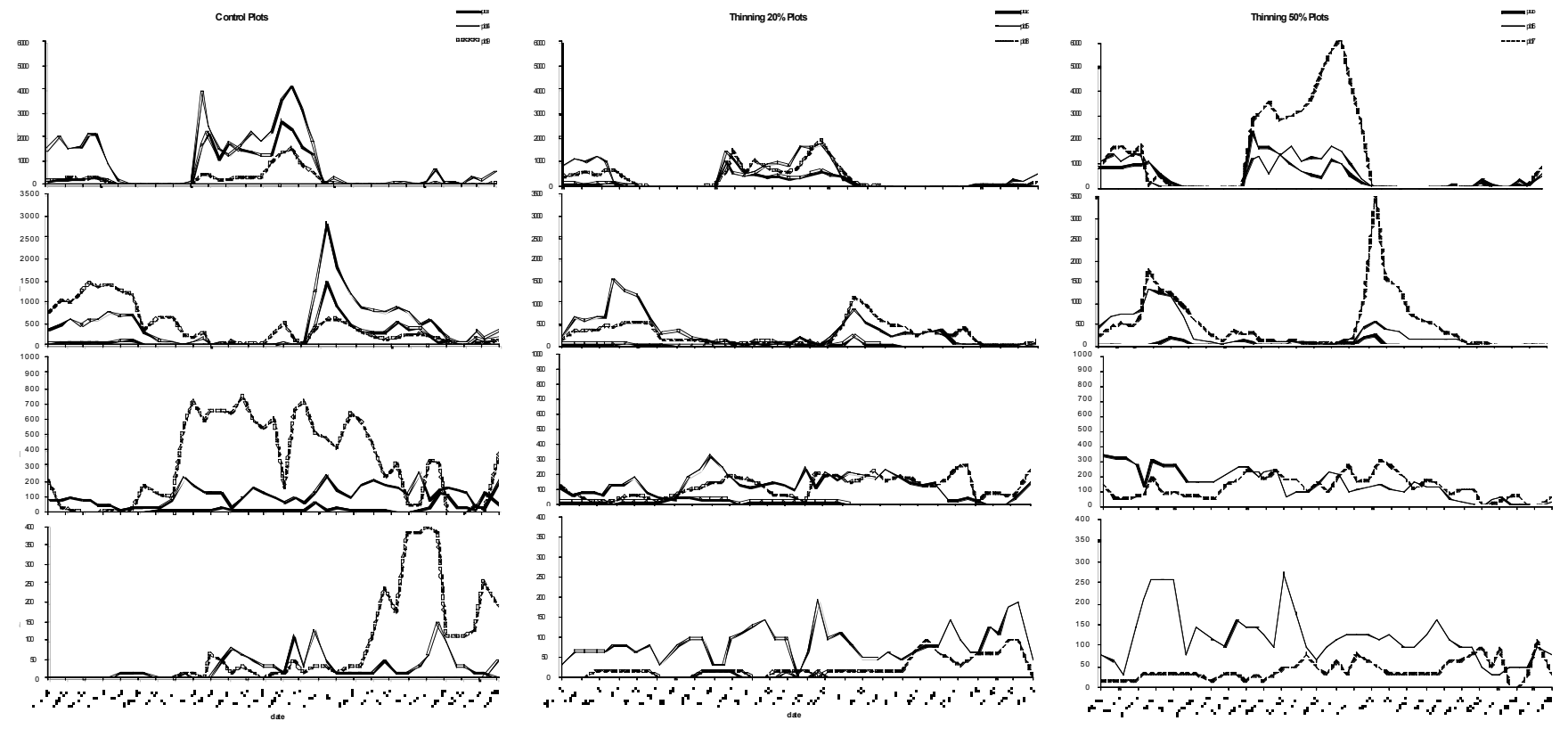

Fig. (4). Density values (per ha) of seedlings, sa_1 (saplings less than one year old), sa_2 (saplings between 1-2 years old) and sa_3 (saplings older than 2 years old) in the control and treated plots (thinned $20 \%$ and thinned $50 \%$ ).

hand, other effects remain, with resprouting density very high in the stems of the treated plots. In the treated plots (thin $20 \%$ and thin $50 \%$ ) there was a low number of dead trees [17], reducing the risk of disease and infection [25]. After 10 years, even cone production was not significantly different among the three treatments.

However, with respect to regeneration, some clear effects remained due to the treatments. Our analysis revealed that germination rate (seedling number) was higher in thin $50 \%$ plots during the entire 2 year period analysed. There was only a $10 \%$ difference in canopy closure, suggesting that the openness is enough to modify insolation and water conditions in the soil [24]. Pinus canariensis is a pioneer species, with a great ability to colonize areas, even those occupied by another species of pine [26]. The promotion of seedlings to other size classes was favoured in control plots, with the largest canopy closure and a higher maintenance of soil humidity because of that.

Results suggest that germination can be favoured by light, and early establishment can be favoured by temperature (in this case independently of treatment, Table 4), as has been seen in other studies [26]. Temperature is important to early stages of Pinus, but not for germination. Finally, saplings older than two years old are more abundant in thin $50 \%$, probably due to several factors. At this stage light [27-29] and site availability [30] that is provided by $50 \%$ thinning of the canopy can be the most important factors in favouring survivorship. These results agree with those of [2] who studies another light-demanding species, Pinus thumbergii.

The effect of thinning management on germination and establishment of species should be evaluated over a period of at least 8-10 years. Opening small and medium gaps in the canopy can favor the germination of seeds, but after a period of a few years (less than 5 years), when the branches of the surrounding trees have almost closed the canopy again, these effect are completely minimized, even though production of seedling is higher. Also, we did not find saplings older than four-five years in the plots, indicating a lack of recruitment at the sites.

Canopy openness should be much larger than that provided by the current management practices, instead offering at least a $40-50 \%$ open canopy for a few years to favor establishment (it should ensure that trees around the gap are unable to close the canopy with their branches). As our results show, germination will be very high, but high mortality is expected and probably not more that $5 \%$ of the individuals survived after 3 years. Larger openness in the canopy will more closely resemble natural stands, where regeneration density is much lower than in plantations $[13,17]$. In this way, individuals remaining after two years will be more resistant to drought and have enough light intensity and more space availability to become established over the next years. These management suggestions may be more successful in maintaining canarian pine forests and obtaining patchier, naturalized stands.

\section{ACKNOWLEDGEMENTS}

We thank Cabildo de Tenerife (Sección de Montes) and Consejería de Política Territorial (Vicenconsejería de Medio Ambiente) for offering some of the data presented in this study, especially initial data related to the different treatments, and also for their financial support. Also we thank the Cabildo of Lanzarote for providing a grant to Esther María Morera (César Manrique Grant Programme) that supported economically the field work period. We also thank Dr. Jerry Husak of Virginia Tech for the edition of the manuscript.

\section{REFERENCES}

[1] Krauchi N, Brang P, Schonenberger W. Forest of mountainous regions, gaps in knowledge and research needs. For Ecol Manage 2000; 132: 73-82.

[2] Zhu J, Matsuzaki T, Lee F, Gonda Y. Effect of gap size created by thinning on seedling emergency, survival and establishment in a coastal pine forest. For Ecol Manage 2003; 182: 339-54. 
[3] Barnett JP, Baker JB. Regeneration methods. In: Duryea ML, Dougherty PM, Eds, Forest regeneration manual, Kluwer Academic Press, Boston, 1991; pp. 3-7: 35-50.

[4] Pickett STA, White PS. The ecology of natural disturbance and patch dynamics. Academic Press. New York; 1985.

[5] Pallardy SG, Cermak J, Ewers FW, Kaufmann MR, Parker WC, Sperry JS. Water transport dynamics in trees and stands. In: Smith WK and Hinckley TM, Eds. Resource physiology of conifers, Academic Press, San Diego, 1995; 301-90.

[6] Parsons JJ. Human influence in the pine and laurel forest of the Canary Islands. Geogr Rev 1981; 71: 253-71

[7] Höllermann P. The impact of fire in canarian ecosystems 19831998. Erkunde 2000; 54: 70-5.

[8] Arévalo JR, Fernández-Palacios JM, Jiménez MJ, Gil P. The effect of fire in the understory of two reforested stands of Pinus canariensis. Tenerife. Canary Islands. For Ecol Manage 2001; 148: 21-9.

[9] del Arco MJ, Pérez de Paz PL, Salas M, Wildpret W. Atlas cartográfico de los pinares canarios. II Tenerife. Viceconsejería de Medio Ambiente. Santa Cruz de Tenerife; 1992.

[10] Ceballos L, Ortuño F. Vegetación y flora forestal de las Islas Occidentales. $2^{\text {nd }}$ Cabildo Insular de Tenerife. S/C de Tenerife; 1974.

[11] Kämmer F. Klima und Vegetation auf Tenerife, besonders in Hinblick auf den Nebelniederschlag. Scripta Geobot 1974; 7: 1-78.

[12] Fernández-Caldas E, Tejedor M, Quantin P. Los suelos volcánicos de Canarias. Servicio de Publicaciones de La Universidad de La Laguna. La Laguna; 1985.

[13] Blanco A, Castroviejo M, Fraile JL, Gandullo JM, Muñoz LA, Sánchez O. Estudio ecológico del pino canario. Serie Técnica No. 6. Ministerio de Agricultura, Pesca y Alimentación. Madrid; 1989.

[14] Izquierdo I, Martín JL, Zurita N, Arechavaleta M. Lista de Especies Silvestres de Canarias. Hongos, Plantas y Animales. Consejería de Política Territorial y Medio Ambiente, Gobierno de Canarias. S/C de Tenerife; 2004.

[15] Köhler L, Gieger T, Leuschner C. Altitudinal change in soil and foliar nutrient concentrations and in microclimate across the tree line on the subtropical island mountain Mt. Teide (Canary Islands). Flora 2006; 201: 202-14.

[16] Arévalo JR, Naranjo A, Salas M. Regeneration in a mixed stand of native Pinus canariensis and introduced Pinus pinea species. Acta Oecol 2005; 28: 87-94.
[17] Arévalo JR, Fernández-Palacios JM. From pine plantations to natural stands. ecological restoration of a Pinus canariensis Sweet, ex Spreng forest. Plant Ecol 2005; 181: 217-26.

[18] Anon. Estudio de la selvicultura en las masas de Pinus canariensis. Informe Consejería Política Territorial. S/C de Tenerife; 1990.

[19] Lemmon PE. A new instrument for measuring forest overstory density. J For 1957; 55: 667-8.

[20] Legendre P, Legendre L. Numerical Ecology. $2^{\text {nd }}$ ed. Developments in environmental modelling 20. Elsevier. Amsterdam; 1998.

[21] Zar JH. Biostatistical analysis. 2nd ed. Prentice-Hall, Englewood Cliffs, NJ; 1984.

[22] SPSS. SPSS/PC+ V.6.0. Base manual. SPSS Inc., Chicago, IL; 1997.

[23] Gagnon JL, Jokela EJ, Moser WK, Huber DA. Characteristics of gaps and natural regeneration in mature longleaf pine flatwoods ecosystems. For Ecol Manage 2004; 187: 373-80.

[24] Lee CS, Kim JH, Yi H, You YH. Seedling establishment and regeneration of Korean red pine (Pinus densiflora S. et Z.) forests in Korea in relation to soil moisture. For Ecol Manage 2004; 199: 423-32.

[25] Smith DM, Larson BC, Kelty MJ, Ashton PM. The practice of silviculture. Applied forest ecology. $9^{\text {th }}$ ed. John Wiley, Sons, Inc. New York; 1997.

[26] Madsen P, Larsen JB. Natural regeneration of beech (Fagus sylvatica $\mathrm{L}$.) with respect to canopy density, soil moisture and soil carbon content. For Ecol Manage 1997; 97: 95-105.

[27] Gobbi M, Schlichter T. Survival of Austrocedrus chilensis seedlings in relation to micro-site conditions and forest thinning. For Ecol Manage 1998; 111: 137-46.

[28] Meer PVD, Digan P, Savench AG. Effect of gap size on seedling establishment, growth and survival at 3 years in mountain ash (Eucalyptus regnans F. Muell.) forest in Victoria, Australia. For Ecol Manage 1999; 117: 33-42.

[29] Myers GP, Newton AC, Melgarejo O. The influence of canopy gap size on natural regeneration of Brazil nut (Bertholletia excelsa) in Bolivia. For Ecol Manage 2000; 127: 119-28.

[30] Oliver CD, Larson BC. (1990) Forest Stand Dynamics. Graw-Hill, New York; 1990.

(C) Arévalo and Palacios; Licensee Bentham Open.

This is an open access article licensed under the terms of the Creative Commons Attribution Non-Commercial License (http://creativecommons.org/licenses/by$\mathrm{nc} / 3.0 /<\mathrm{http}: / /$ creativecommons.org/licenses/by-nc/3.0/>) which permits unrestricted, non-commercial use, distribution and reproduction in any medium, provided the work is properly cited. 